\title{
BUSINESS SUSTAINABILITY PRACTICE AND OPERATIONAL MANAGEMENT INHOTEL INDUSTRY IN AQABA SPECIAL AUTHORITY ECONOMIC ZONE AUTHORITY (ASEZA)
}

\author{
Omar JAWABREH* \\ The University of Jordan, Faculty of Tourism and Hospitality, Department of Hotel Management, Jordan, e-mail: o.jawabreh@ju.edu.jo
}

Haitham ABDELRAZAQ

University of Western Sydney, School Business, Australia, e-mail: haithamabdelrazaq@gmail.com

Ashraf JAHMANI

Al-Ahliyya Amman University, Business School, Jordan, e-mail: ajahmani@ammanu.edu.jo

\begin{abstract}
Citation: Jawabreh, O., Abdelrazaq, H., \& Jahmani, A. (2021). BUSINESS SUSTAINABILITY PRACTICE AND OPERATIONAL MANAGEMENT INHOTEL INDUSTRY IN AQABA SPECIAL AUTHORITY ECONOMIC ZONE AUTHORITY (ASEZA). GeoJournal of Tourism and Geosites, 38(4), 1089-1097. https://doi.org/10.30892/gtg.38414-748
\end{abstract}

\begin{abstract}
The objectives of this paper are to explore the understanding of tourism through business sustainability through the management of the environmental and operating practices of five-star hotels in Aqaba Jordan. Data would be obtained from a variety of outlets, including paper analyses, impressions, and questionnaires. Semi-structured interviews are typically used to retrieve and supply details. The primary purpose of such interviews is to collect contextual knowledge from the sampled community. It also seeks to include useful knowledge on specific problems and to gain a range of perspectives on specific issues. It is planned to pilot the paper and pencil surveys and the test details to be gathered by field visits and semi-structured interviews. The findings reveal that hotels in Aqaba have used reuse or recycle glass or plastics. In order to encourage sustainable practices in the hotel industry in Jordan, we need to build distinction and competitive advantages by cost savings. The sustained success of economic operations is of utmost importance to companies, whether in the production or service sectors. This emphasis on sustainability is especially relevant to the growth of tourism and hospitality destinations. Established and Emerging economies have embraced environmental and organizational sustainability as a core.
\end{abstract}

Key words: perception, sustainability, operational management, sustainability, environmental, Aqaba

\section{INTRODUCTION}

Sustainable performance of business activities is highly essential for businesses, whether in the manufacturing or services industry. This focus on sustainability is particularly significant in developing tourism and hospitality destinations. Developed and Developing economies have adopted environmental and operational management as a key focus of their hospitality and tourism enterprises. Europe in particular has a variety of globally recognized environmental schemes, and includes the European Eco-Management, the International ISO-14001, Audit Scheme (EMAS), and the European Eco-label scheme. Some hotels are still resistant to "greening behavior" such as investing in environmental protection initiatives and introducing environmental protection measures. These companies believe that these initiatives require considerable capital investment; they do not bring any significant financial benefit to the hotel (Eshun and Tichaawa, 2020; Maaiah and Wouhoush, 2020; Jinha and Youn-Kyung, 2020; Rizal et al., 2020; Trip et al., 2021; Kang et al., 2012). Furthermore, some scholars have found consumers to be ambiguous about purchasing environmentally friendly products (Jones et al., 2016; Kuqi, 2018; Liesbeth, 2004).

The roots of environmental thought in the hospitality sector became evident over half a century ago, when a few enterprising hoteliers realized they could provide an enhanced guest experience by integrating natural elements into the resort experience. This concept, which evolved from earlier land conservation efforts, was pioneered in such locations as Caneel Bay and the Maho Bay Camps in the U.S. Virgin Islands. Key events in the decades that followed are briefly outlined below (Demetra et al., 2021; Olya et al., 2020; Sayfuddin, 2021). The focus of this study is to examine the perception of tourist through business sustainability through the management of environmental and operational practices of five star hotels in Aqaba Jordan. Environmental management is gaining significant recognition among businesses all over the world. Attaining positive and favorable environmental and operational performance largely drives the activities of businesses. As indicated by Kirk (1995), the concern related to the management of environmental performance is mainly associated with industries such as tourism, which account for direct pollution from their business practices. However, during the 1990s the subject of sustainable and better operational environmental performance has led to the expansion of sustainability of business in various other industries. Environmental protection and conservation have become important to the hotel industry from the perspective of government, consumers and the industry itself. Rapid economic development has

\footnotetext{
* Corresponding author
} 
caused environmental pollution and destruction. As a result, the government, industry and consumers are highly concerned about environmental conservation. Zhenhua Liu, 2003; Singh et al., 2011; Wang et al., 2013; Xing and Kara, 2013; Xun and Dogan, 2015; Yaiza, 2011; Zhang et al., 2012).The hospitality industry is one such example, having faced significant concerns about managing the performance towards the environment and the need to adopt sustainable practices.

The number of resources to assist hotel owners and operators in understanding and implementing sustainability measures is vast. These resources are provided by international organizations, public agencies (national and local governments), environmental firms, architectural and engineering consultancies, energy firms, utilities, trade organizations, and other entities (Hwai-Shuh, 2012; Karolina, 2017; Lei et al., 2011; Masadeh et al., 2019; Masa'deh et al., 2017; Ángeles et al., 2017; María del Mar et al., 2018; Sajjad et al., 2018; Sainaghi et al., 2018). The purpose of this research is to investigate sustainable environmental performance in five star hotels in Aqaba, Jordan. The primary objective of the research is to determine the impact of business and operational practices of five star hotels in Aqaba. This will be determined by conducting data collection from the main stakeholders such as guests, hotel managers and suppliers through their responses and conducting literature reviews from brochures and artifacts. The data collected will then be analyzed through qualitative analysis.

\section{LITERATURE REVIEW}

Sustainable practices as adopted by hotels are highly favored by customers and their higher satisfaction level makes them loyal towards the hotel. Keeping existing guests and repeat visitation is a constant theme when discussing profitability in the service industry. Guests are becoming increasingly attracted to hotels that have gone 'green' and are seen to be employing active environmental conservation measures. According to Kang et al. (2012), Consumer willingness to pay a premium for green initiatives is significantly higher, making an investment in green practices attractive to hoteliers. Generally, hotels practicing effective sustainability programs improve their sustainability programs and stand a better chance of gaining Green Globe certification. The major challenge for the hotel industry is instilling change in their business operations. Hotels operate with the main motive of enhancing their profitability. It is becoming increasingly important that hotels consider stakeholders like the community, government, society and the environment. Studying the business sustainability topic from an organization change viewpoint helps us to understand better why efforts by stakeholders to implement sustainable development only realize partial success, says Blomme et al., (2013). Second, the theoretical perspective to be applied is that of Strategic Management Theory in the discussion of environmental and operational management practices in the hotel industry. Hotel chains in the higher star levels (four and five star) are more actively engaged in initiatives that address issues directly linked to environmental sustainability (Richard, 2000; Saleh and Hassan, 2000; Wyngaard and Lange, 2013).Operational decisions such as the management of waste and consumption of various significant natural resources, design and human resource practices should be undertaken in a manner that leads to their strategic use and advancement in the overall efficiency of hotels. Both Stakeholder Theory and Strategic Management theory and approaches will be canvassed in the literature.

Sustainable tourism, according to Forsyth (2003), is the consequence of and imitation of sustainable development (SD). According to him, sustainable development refers to production that satisfies current demands while also having the capacity to satisfy future generations' needs. While concise, this explanation overlooks the difficulties of putting the concept into practice. This is due to a number of impediments to sustainable development, most notably in terms of the idea and reach of sustainable techniques, as well as the sectors in which they operate (Berezan et al,. 2013; Chen, 2009). In addition to enhancing the perceived product quality (Reinartz et al., 2004), CRM stands for Customer Relationship Management, and it refers to the joint effort with each customer because the firm adds value to their life, and they express their gratitude by remaining loyal to the brand. This is a personalized agreement with each client that seeks to identify and keep the greatest consumers while also expanding the company's knowledge of their particular requirements, fulfilling their expectations of the organization, and making a positive impact in their lives (Jawabreh et al., 2020).Customer satisfaction must be improved in order to retain client loyalty. Today, the most important thing to do to enhance customer happiness is to adopt consumer-centered practices that are customized to the needs and values of each individual customer (Jens andSteen,2007). Customer loyalty is described as the long-term and ongoing retention of a relationship via the provision of service that meets, if not exceeds, the customer's needs (Iraldo et al,. 2017).

Hwan and Ercan, S (2005) create indicators to track community tourism development (CTD) in a long-term context. This research used a modified Delphi method to generate such objective indicators. The indicators were developed with the help of a panel of 38 academic tourism researchers. After three rounds of deliberation, panel members agreed on the following 125 indicators for CTD: political (32), social (28), ecological (25), economy (24), technical (3), and cultural aspects (13). This collection of sustainable tourism indicators may be used to develop a set of indicators at the local and regional levels. Further research will be conducted to develop a set of sustainable indicators based on the unique characteristics of communities and involving indicator experts from the social and physical sciences as well as representatives from all stakeholder groups, including residents of the host community, industry experts, government planners, policy-makers, and non-governmental organizations (Fanni and Rezazadeh, 2018; Hardy and Beeton, 2001). Introduces a comprehensive new competitive model that focuses on environmental sustainability aspects related to tourism destinations. Because of the variety of industries involved in destination planning and development, a competency model that examines the relationships among all stakeholders involved in creating and integrating value-added products to sustain resources while maintaining market position relative to other competitors is required. Future destination growth must be led by a competent and efficient management with a focus on a sustainable client base. As a result, destination management 
should concentrate on a thorough evaluation of distinctive comparative advantages that offer a unique long-term attraction to the target travel consumer groups. As a result, a particular destination's lifespan becomes a consequence of reacting to market demand and competitive difficulties. Future destination development plans must be consistent with market demands and environmental integrity in order for the sector to remain economically viable. According to research performed by Webster (2000), increased public knowledge forces companies to concentrate on attaining long-term success. According to the findings, environmentally aware consumers are willing to pay a greater premium for a company that implements greener business methods. According to Mensah (2006), the necessity for environmentally aware consumers to buy from green businesses, as well as development possibilities, has been the main pushing force for hotels in attaining environmentally friendly and sustainable overall performance. Webster (2000) goes on to emphasize the need to promote sustainability measures in terms of public relations. Publication of sustainability indicators in reports, as well as acknowledgment of major proactive actions taken to improve overall environmental and sustainable performance, are an additional benefit. Apart from that, the sustainable measures taken by hotels are also recognized in relation to their buying habits. Purchasing activities and considerations such as purchasing recyclable materials rather than single-use materials, encouraging seller firms to partner in recycling, purchasing from local firms, purchasing less hazardous cleansers, and purchasing energy-saving materials are all examples of environmental sustainability in action (Mensah, 2006). Hotels aiming for sustainable performance may then apply transformational approaches to the overall performance of the hotel by concentrating on these areas (Erdogan and Baris, 2007; Aswita et al., 2018; Eshun and Tichaawa, 2020).

Many of the results of Masa'deh et al., 2017) research on environmental management practices in hotels in Aqaba, Jordan, were found to be similar in terms of sustainable strategies implemented by hotels. The presence of an environmental policy, the appointment of a dedicated environmental manager, the use of natural ventilation rather than air conditioning, the installation of dual flush toilets, encouraging guests to be environmentally conscious, and assisting hotel managers in achieving green performance were all implemented. To accomplish sustainability, the hotel utilized recycled paper goods, produced environmentally friendly project information for visitors, and, most significantly, supported the local community in which it operated. Hotels may launch public awareness programs to assist the local population realize the significance of avoiding the use of paper goods in the environment (Masa'deh et al., 2017).

\section{METHODOLOGY}

Data collected from multiple sources, which include document reviews, observations and questionnaires. Semistructured interviews are usually used to retrieve and offer information. The main aim of such interviews is to get qualitative information from a sampled population. It also aims at getting information important to specific issues and gains a number of insights into specific issues. It is intended to pilot test the paper and pencil surveys and test information to be collected through a field visit and semi structured interview. The information collected is analyzed by the researcher and missing data or questions can be identified to revise the surveys (Chin, 2010; Reinartz et al., 2009). The research was carried out with an open framework, which allows for conversational and focused two-way communication. This method helps the field staff to know community members. Outsiders could be availed during the interview, as they are more objective. Group and individual interviews can be conducted to get more objective information. The survey analyzed using descriptive and thematic frequency counting. The use of a psychometrically tested instrument like the EMS/EIA for the research ensures validity and reliability. The researcher needs to consider ethical values in performing the collection of data, in order to achieve accuracy and reliability of the collected data. This ethical compliance is monitored by completing and receiving approval from the National Ethics Application Form (NEAF) This provides safeguards for the researcher and increases the credibility of the research. For this project, limitations may arise in terms of commercial in confidence information and managers may require the researcher to sign non-disclosure clauses (Bagozzi and Yi, 1988). Thematic analysis collating information from the interviews broadly categorized environmental and operational aspects of business sustainability. The inclusion of photographs and other artifacts used to provide data. The presentation of study findings as tables and Graphs for responses on EMS/ EIA descriptive data.

\section{AQABA}

The modern name of Aqaba came from the ancient name of "Aqabat Aila' which means "the pass of Aila", a reference to the route north of Ma'an city, in the South of Jordan. Given its strategic location on a number of trade and pilgrimage routes, Aqaba attracted many conquerors throughout its history. Ptolemies, Nabataeans, Romans, Crusaders and Ottamans are to name but a few of those dynasties who once ruled Aqaba. Located at the Southern tip of Jordan, Aqaba represents Jordan's only port access to the outside world through the Red Sea. From Aqaba's city center, the borders of Israel, Egypt and Saudi Arabia are within easy reach. Aqaba is reachable by land, sea and air through a network served by both a deep-water seaport, an international airport and various motorways. The aim is for Aqaba to become an international destination attracting investments from all over the globe and to be the catalyst for economic development in the south of Jordan. A study on the prospects of Aqaba was undertaken by the World Bank and the concept of a public-private partnership was taken forward. The Aqaba Special Economic Zone (ASEZ) was launched in February 2001 as a duty-free, low tax and multi-sector development zone offering global investment opportunities in a world-class business environment ranging from tourism, professional services, multi-model logistics and manufacturing. ASEZ is spread over an area of $375 \mathrm{~km}$ covering the total Jordanian coastline $(27 \mathrm{~km})$, the seaport, the international airport and the historical city of Aqaba. Beside the many hotels in Aqaba (41 classified hotels) that offers events 
facilities, three huge touristic projects are being constructed and will resume their functions in 2014 and the next years. These projects (Saraya Aqaba, Ayla Oasis, and Marsa Zayed) will have many five star hotels beside convention centers devoted for MICE and local events. Moreover, to public universities are teaching tourism and hospitality for their undergraduate students and event management course is compulsory that students should take during their learning years in these two universities. In Jordan, resort properties that operate in places like Aqaba, Petra and the Dead Sea are particularly vulnerable to environmental degradation and the loss of the natural environment. Umaima Al Majthoub (2008) notes worrying trends related to water, energy and land degradation related to the tourism industry in Jordan.

The importance of mitigating adverse impacts on the environment in which hotels operate is also gaining momentum (Sweeting and Sweeting, 2002). Further, as suggested by Molina-Azorin et al., 2009), commitment towards the natural environment is an important variable within the current competitive scenario and environmental initiatives by organizations can lead to the attainment of competitive advantage and improved performance levels. There are various benefits possible through adopting sustainable practices, but the issue of long lasting threats includes impacts on fragile eco-systems, flora, fauna and competition with local people for scarce resources especially energy and water. Hence, it is imperative that the government and hospitality providers manage environmental performance through sustainable practices, ensuring the long-term viability of the tourism and hospitality industry.

\section{STABILITY OF THE TOOL}

The stability of the tool has been tested by Cronbach's alpha coefficient test, and by considering of the Table 1 it's clear that all values greater than 0.60 then there is stability in the study tool. As shown in Table 3, that, except paragraph No. 3, all other paragraphs got greater than 3.00 mean and significance level less than 0.05 it means that it has Statistical Significance.

Table 1. Cronbach's alpha test results:

\begin{tabular}{|l|c|}
\hline \multicolumn{1}{|c|}{ Fields } & Alpha value \\
\hline $\begin{array}{l}\text { Business and operational practices are followed by } \\
\text { five-star hotels in Aqaba Jordan to achieve sustainable } \\
\text { environmental performance. }\end{array}$ & 0.89 \\
\hline $\begin{array}{l}\text { The levels of Awareness and Attitudes of Management } \\
\text { and Stakeholders toward Environmental Sustainability } \\
\text { Measures in five-star hotels in Aqaba Jordan. }\end{array}$ & 0.83 \\
\hline $\begin{array}{l}\text { Environmental audits practiced by five-star hotels in } \\
\text { Aqaba Jordan. }\end{array}$ & 0.78 \\
\hline Total & 0.84 \\
\hline
\end{tabular}

Table 2. The frequencies and percentages for personal and functional variables of respondents

\begin{tabular}{|l|l|c|c|}
\hline Variable & Variable categories & No. & Percentage \\
\hline Gender & Male & 80 & $72 \%$ \\
\cline { 2 - 4 } & Female & 31 & $28 \%$ \\
\hline \multirow{5}{*}{ Age } & Less than 20 years & 5 & $4.5 \%$ \\
\cline { 2 - 4 } & $21-30$ years & 50 & $45 \%$ \\
\cline { 2 - 4 } & $31-40$ years & 33 & $29.7 \%$ \\
\cline { 2 - 4 } & $41-50$ years & 10 & $9.1 \%$ \\
\cline { 2 - 4 } & $51-60$ years & 13 & $11.7 \%$ \\
\hline \multirow{5}{*}{ Income } & Less than $1000 \$$ & 80 & $72 \%$ \\
\cline { 2 - 4 } & $1001 \$-2000 \$$ & 20 & $18 \%$ \\
\cline { 2 - 4 } & 2001\$ - 3000 & 7 & $6.4 \%$ \\
\cline { 2 - 4 } & more than 3001 \$ & 4 & $3.6 \%$ \\
\hline \multirow{5}{*}{ Education } & Private Sector & 111 & $\% 100$ \\
\cline { 2 - 4 } & Public Sector & 0 & 0 \\
\cline { 2 - 4 } & High School & 15 & $13.5 \%$ \\
\cline { 2 - 4 } & Bachelors degree & 84 & $75.6 \%$ \\
\cline { 2 - 4 } & Masters degree & 10 & $9.1 \%$ \\
\cline { 2 - 4 } & Post Graduate degree & 2 & $1.8 \%$ \\
\hline
\end{tabular}

Paragraph No. 4 which relates to Hotels in Aqaba used Reuse or recycling glass or plastics at the first rank and a mean of 4.1623. Paragraph No. 1 which related to the sustainability mean to the customer Proper use of water and energy at the second rank with a mean 4.1622. Then paragraphs 2 came, respectively, in the third and fourth rank, Paragraph No. 17 which related Hotels in Aqaba used green power such as solar heating. Paragraph no 3 came in the last rank with a mean of 2.6577.

Table 3. Mean, standard deviations and the level of significance for Business and operational practices are followed by five-star hotels in Aqaba Jordan to achieve sustainable environmental performance

\begin{tabular}{|c|l|c|c|c|}
\hline No & \multicolumn{1}{|c|}{ Paragraph } & mean & S.D & level of significance \\
\hline 1 & Sustainability means to the customer Proper use of water and energy & 4.1622 & .78091 & 0.00 \\
\hline 2 & Sustainability means to the customer Purchasing Green items & 4.0180 & .76256 & 0.00 \\
\hline 3 & Sustainability mean to you minimal wastage of food & 2.6577 & .81459 & 0.00 \\
\hline 4 & Sustainability means Getting awards for maintaining sustainability & 3.7387 & .73499 & 0.00 \\
\hline 5 & Sustainable environmental management in the Hotel Industry specifically in the Jordanian context & 3.8829 & .77152 & 0.76 \\
\hline 6 & Categories sustainability practices carried out by your Hotel Priority & 3.7387 & .82805 & 0.01 \\
\hline 7 & Categories sustainability practices carried out by your Hotel Energy Saving & 3.5405 & .86112 & 0.00 \\
\hline 8 & Categories sustainability practices carried out by your Hotel Green Purchasing & 3.6667 & .89781 & 0.02 \\
\hline 9 & Categories sustainability practices carried out by your Hotel Water Saving & 3.9099 & .85864 & 0.00 \\
\hline 10 & Categories sustainability practices carried out by your Hotel Waste Minimization & 3.5495 & .77152 & 0.00 \\
\hline 11 & Categories sustainability practices carried out by your Hotel Solid Waste Management & 3.5405 & .72342 & 0.00 \\
\hline 12 & Hotels in Aqaba used Energy saving bulbs & 3.4324 & .83798 & 0.00 \\
\hline 13 & Hotels in Aqaba used Portion control to minimize food wastage & 3.7207 & .75283 & 0.00 \\
\hline 14 & Hotels in Aqaba used Low flush toilets & 3.4865 & .98963 & 0.00 \\
\hline 15 & Hotels in Aqaba used Categorizing garbage collection for recycling & 3.5405 & .86112 & 0.00 \\
\hline 16 & Hotels in Aqaba used Low flow shower heads less than 2.5 gal/minute & 3.2973 & 1.03216 & 0.00 \\
\hline 17 & Hotels in Aqaba used green power, such as solar heating & 3.9640 & .74988 & 0.00 \\
\hline 18 & Hotels in Aqaba used Towel reuse program & 3.9009 & .67359 & 0.00 \\
\hline 19 & Hotels in Aqaba used Reuse or recycling glass or plastics & 4.1623 & .94657 & 0.00 \\
\hline & Total & 3.882 & .64651 & 0.00 \\
\hline
\end{tabular}


Paragraph No. 5 has got a larger than 3.00 mean values, but its level of significance is greater than 0.05 , meaning it is not statistically significant, which means that there is no Sustainable environmental management in the Hotel Industry specifically in the Jordanian context. The paragraphs have got together 3.882 mean values and level of significance less than 0.05 , meaning it is statistically significant, therefore the first hypothesis are accepted where Business and operational practices are followed by five star hotels in Aqaba Jordan to achieve sustainable environmental performance. As shown in table (4), that paragraphs got greater than 3.00 mean and significance level less than 0.05 it means that it has Statistical Significance. Paragraph No. 27 which relates to Hotels in Aqaba Need to create differentiation and competitive advantage through cost savings at the first rank and a mean of 3.9640. Paragraph No. 20 which related to the important sustainability practice in your hotel Financial saving at the second rank with a mean 3.8378. Then paragraphs 31, Cost saving measures, came in the third and fourth rank, Paragraph No. 25 which related Importance of conserving the natural resources. Paragraph no 24, Pressure from consumers in the industry such as guests and travel agents came at the last rank with a mean of 3.2703. Although Paragraph No. 25 has got a larger than 3.00 mean values, but its level of significance is greater than 0.05 , meaning it is not statistically significant, which means that there is no Pressure from owners and shareholders. The paragraphs have got together 3.7703 mean values and level of significance less than 0.05 , meaning it is statistically significant, therefore the first hypothesis are accepted where the levels of Awareness and Attitudes of Management and Stakeholders toward Environmental Sustainability Measures in five star hotels in Aqaba Jordan.

Table 4. Mean, standard deviations and the level of significance for the levels of Awareness and Attitudes of Management and Stakeholders toward Environmental Sustainability Measures in five-star hotels in Aqaba Jordan

\begin{tabular}{|l|l|c|c|c|}
\hline No & \multicolumn{1}{|c|}{ Paragraph } & Mean & S.D & Level of significance \\
\hline 20 & Important sustainability practice in your hotel Financial Saving & 3.8378 & .84789 & 0.00 \\
\hline 21 & An important sustainability practice in your hotel, as well as increased consumer awareness. & 3.6847 & .83101 & 0.00 \\
\hline 22 & $\begin{array}{l}\text { In your hotel, you have an important sustainability practice. Benefits that last a long time, } \\
\text { such as environmental conservation }\end{array}$ & 3.6306 & .95278 & 0.00 \\
\hline 23 & Important sustainability practice in your hotel Customer Retention & 3.3604 & .86121 & 0.00 \\
\hline 24 & Pressure from consumers in the industry such as guests and travel agents & 3.2703 & 1.03525 & 0.00 \\
\hline 25 & Pressure from owners and shareholders & 3.2973 & .95912 & 0.07 \\
\hline 26 & Internal and External Green Championship campaigns & 3.3423 & 1.04007 & 0.00 \\
\hline 27 & Need to create differentiation and competitive advantage through cost savings & 3.9640 & .89369 & 0.02 \\
\hline 28 & Need to retain customers & 3.5856 & .90923 & 0.00 \\
\hline 29 & The importance of conserving the natural resources & 3.6486 & .97839 & 0.00 \\
\hline 30 & Government regulations & 3.5946 & .80202 & \\
\hline 31 & Cost saving measures & 3.7027 & .72104 & 0.00 \\
\hline & Total & 3.7703 & .60597 & 0.00 \\
\hline
\end{tabular}

Table (5) shows that all paragraphs have Statistical Significance when the mean is higher than 3.00 and the significance threshold is less than 0.05. No. 36, which, in your view, pertains to Hotel Management's promotion of sustainable practices in the hotel sector in Jordan, is ranked top with a mean of 3.8910. The paragraph No. 41, which you believe hinders environmental conservation in the Jordanian hotel sector, is ranked second with a mean of 3.8910 . Then came paragraphs 32 and 38, which related to how committed is your Hotel to providing resources (money, time, people) towards sustainable practices in relation to the overall income less than 50\%, and paragraph No. 38, which related to how committed is your Hotel to providing resources (money, time, people) towards sustainable practices in relation to the overall income less than $50 \%$ with a mean of 3.5676 , paragraph no35 came in last.

Table 5. Mean, standard deviations and the level of significance for

Environmental audits practiced by five-star hotels in Aqaba Jordan

\begin{tabular}{|c|c|c|c|c|}
\hline No & Paragraph & Mean & S.D & $\begin{array}{c}\text { level of } \\
\text { significance }\end{array}$ \\
\hline 32 & $\begin{array}{l}\text { The percentage of costs does your Hotel save in promoting the use of sustainable management } \\
\text { measures in relation to the overall income less than 50\% }\end{array}$ & 3.7928 & .79906 & 0.00 \\
\hline 33 & $\begin{array}{l}\text { The percentage of costs does your Hotel save in promoting the use of sustainable management } \\
\text { measures in relation to the overall income more than } 51 \%\end{array}$ & 3.6667 & .90788 & 0.00 \\
\hline 34 & In your opinion Hotel Owners to promote sustainable practices in the hotel industry in Jordan & 3.6577 & .89945 & 0.00 \\
\hline 35 & In Jordan's hotel sector, do you think the government should encourage sustainable practices? & 3.5676 & .98739 & 0.00 \\
\hline 36 & In your opinion Hotel Management to promote sustainable practices in the hotel industry in Jordan & 3.8919 & .92787 & 0.00 \\
\hline 37 & Customers, in your view, should encourage sustainable practices in Jordan's hotel sector. & 3.6757 & .89607 & 0.00 \\
\hline 38 & $\begin{array}{l}\text { How committed is your Hotel to providing resources (money, time, people) towards sustainable } \\
\text { practices. (Please circle your answer) }\end{array}$ & 3.6847 & .98148 & 0.00 \\
\hline 39 & Sustainability in the Hotel Industry still an issue in Jordan & 3.6577 & .97697 & 0.08 \\
\hline 40 & In your opinion hampers environmental conservation in the Jordanian hotel industry Poor Regulation & 3.6306 & .77375 & 0.00 \\
\hline 41 & In your opinion hamper environmental conservation in the Jordanian hotel industry High cost & 3.8910 & .66540 & 0.00 \\
\hline 42 & In your opinion hampers environmental conservation in the Jordanian hotel industry Lack of expertise & 3.5856 & .79164 & 0.01 \\
\hline \multirow[t]{2}{*}{43} & In your opinion hampers environmental conservation in the Jordanian hotel industry Ignorance & 3.4144 & .94838 & 0.00 \\
\hline & Total & 3.6036 & .61095 & 0.00 \\
\hline
\end{tabular}


Although the mean value of paragraph No. 39 is higher than 3.6577, the level of significance is greater than 0.05 , indicating that it is not statistically significant, implying that sustainability in the hotel industry is still a problem in Jordan.The paragraphs no 40 have a mean value of 3.6036 and a level of significance of less than 0.05 , indicating that it is statistically significant. Thus, the third hypothesis is accepted. Five-star hotels in Aqaba, Jordan, do environmental audits.

Table 6. One-Sample Test

\begin{tabular}{|c|c|c|c|}
\hline Dimension & $\mathbf{t}$ & df & Sig. (2-tailed) \\
\hline $\begin{array}{l}\text { Business and operational practices are followed by five star hotels in Aqaba Jordan to achieve sustainable } \\
\text { environmental performance. }\end{array}$ & 63.276 & 110 & .000 \\
\hline $\begin{array}{l}\text { The levels of Awareness and Attitudes of Management and Stakeholders toward Environmental } \\
\text { Sustainability Measures in five star hotels in Aqaba Jordan. }\end{array}$ & 65.552 & 110 & .000 \\
\hline Environmental audits practiced by five star hotels in Aqaba Jordan. & 62.143 & 110 & .000 \\
\hline
\end{tabular}

\section{RESULTS}

This study aimed to demonstrate tourist perceptions of business sustainability, environmental management, and operational management in five-star hotels in Aqaba city, and we can infer the most important findings of the researcher during the study by referring to the study, data analysis, and test hypotheses. First, at the level of significance (0.05> $\alpha$ ), there is statistically significant to Hotels in Aqaba utilized. Glass or plastics are reused or recycled first, with a mean of 4.1623. Second result: At the level of significance $(0.05>\alpha)$, there is statistically significant. The levels of awareness and attitudes of management and stakeholders toward environmental sustainability measures at five star hotels in Aqaba, Jordan are accepted as the first hypothesis. The third hypothesis: Because the third hypothesis is statistically significant at the level of significance $(0.05>\alpha)$, it is accepted. Five-star hotels in Aqaba, Jordan, do environmental audits.

It was discovered that $(50 \%)$ of them are ready to pay an extra fee of $10 \%$ for their stay in the Green Hotel, and $(60 \%)$ of them have reservations about certain hotels' efforts on their electronic websites in this respect. The (International Business Leaders Forum) (ABLF) encouraged the spread of this trend in the hotel industry, as well as the general tourism and travel industries, so it established the (International Tourism Partnership) (ATB) in 1992 in a serious attempt to diagnose the sector's disadvantages and deficiencies in terms of the environment, as well as finding ways to address them. - First, educate hotel guests about the significance of water and the necessity for them to help save it by limiting their usage as much as possible and recognizing the legal status of the devices and additives used in its legalization. Second, encouraging prisoners to use towels and linens as little as possible in order to save water and minimize the use of detergents and powders in the washing process, both of which contribute to pollution. Third, in order to conserve money, ensure that the water they use has sufficient pressure by adding air to it.

Fourth, saving the prisoners' electrical energy via optional lighting and other means, such as limiting the required illumination and not over-operating the hotel room's electrical equipment. And among the leading green hotels in this field is a chain (Fairmont Hotels and Resorts) that entered into a partnership with the (Environmental Sustainability Program) (Green Key), which is recognized by (the American Hotels and Hostels Association) and recommended by (the Forest Alliance Organization) Al-Matarah, and that has been doing so since the 1990s until all of its hotels and resorts in North America have been certified. The Partnership for Sustainable Global Standards and the White House's "Environmental Sustainability Council" are both reported to be interested in this initiative. The (Fairmont Hotels and Resorts Chain) hve also launched a group of innovative guest accommodation offers that benefit nature in a variety of ways, such as the (Fairmont Royal Pavilion) hotel in Barbados, which has established a specialized team to monitor sea turtles and document their life cycles under the watchful eye of guests. And the (Fairmont Orchid) hotel in (Hawaii) monitoring and following up on its coral reefs in collaboration with the University of Hawaii, and the (Fairmont Bab Al Bahr) hotel in Abu Dhabi, United Arab Emirates, organizing trips for guests in the many lakes and islands surrounding the hotel (200 islands) and watching birds, fish, and animals in order to feel nature and a proper int The Austrian Imperial Hotel, which won the Tourism awards for Environmental Preservation, was one of twelve hotels nominated in Austria, for adopting an advanced engineering system to save electrical energy, as well as a lighting system that has proven effective and is based on automatically extinguishing (50 percent) of the lighting network after the (11) a.m. $(10,000)$ During the year, a house, and the use of water sprays for cleaning, which saves (400) million liters of water per year, and the use of baskets to collect and sort the remains and waste in the hotel, whether metal, plastic, or food, for the purpose of processing and recycling as much as possible, and choosing detergents and sterilizers with as little impact on the environment as possible without compromising the quality, and choosing detergents and sterilizers with as little impact on the environment as possible without compromising In addition, the (InterContinental Dubai Festival City) hotel in Dubai, United Arab Emirates, has transformed its exterior lighting system, saving $10 \%$ of electrical energy yearly and using lighting bulbs with a $22 \%$ longer operational life than previous lamps.

The topics of integrated environmental and economic accounts and the green economy have received a lot of attention in recent years because they are critical in achieving sustainability and achieving it through the integration of its three main components, which include economic growth, environmental sustainability, and social welfare, as well as measuring growth in the green economy (Jawabreh, 2017; Abujamous et al., 2018; Alananzeh et al., 2018; Anna, 2005; Aragon-Correa et al., 2015; Heydari and Bakhtar, 2018; Idahosa, 2019; Karim et al., 2018; Rizal et al., 2020; Singtuen and Won-In, 2020; Strydom et al., 2020; Strydom et al., 2019). The integration of environmental and economic 
accounting is critical for assessing the effect of economic activity on the environment as well as the advantages that the environment provides to the economy. The findings of the 2019 environmental surveys demonstrated the significance of the green economy by evaluating environmental investment and green employment created by this investment, which seeks to preserve and manage the environment while also providing environmental products and services. Environmental expenditure data is important because it can be used to track the costs of switching from a traditional manufacturing process to one that is more environmentally friendly, or to pay additional costs for proper waste and wastewater disposal, pollution reduction, and other environmental protection activities, or as a response to environmental laws and regulations that govern the process. The Millennium Goals' seventh objective is to protect the environment by permanently providing environmental services and commodities, such as providing a clean and sustainable supply of water for the people. The financial expenditures for environmental protection and management by the medical services sector, both public and private, and the municipal, industrial, and service sectors (hotel and education activities) were included in the study of environmental expenditures for the year 2019 (Azilah et al., 2014; Chan et al., 2016; Cheng-Yue et al., 2020; Christopher et al., 2018; Eirini et al., 2019; Emmanouela et al., 2016; GomezConde et al., 2019). The public sector is (government ministries and universities). These sectors' environmental expenditure reflects their own responsibilities for environmental protection and management.

According to the findings, the municipal sector spent the greatest money on environmental protection, spending 61.5 million dinars. Operating costs accounted for 89 percent of expenditures, while capital expenditures accounted for 11 percent. Self-financing accounted for 97 percent of the total, while government assistance accounted for just $1 \%$. The medical services industry came in second with 7.2 million dinars invested, with $41 \%$ of it goes to operating costs and $59 \%$ going to capital expenditures. The third-placed industrial activities sector (hazardous industries and certain industrial activities) spent 6.7 million dinars, with operating expenses accounting for 47 percent and capitalism accounting for 53 percent. The services sector (hotel and educational activities) came in last, with 1.4 million dinars in spending, 64 percent of which was operating costs and 36 percent of capital expenditures (Pereira-Moliner et al., 2015; Santos et al., 2019; Sloan et al., 2009; Pereira-Moliner et al., 2015; Santos et al.,2019). The goal of the study is to gather comprehensive information on the status of five-star hotel sustainability practices. Surveys and field visits, as well as artifacts and semistructured interviews, will be used to achieve methodological triangulation. The respondents will come from Jordan's five-star hotels that are actively involved in corporate sustainability efforts.

The standard method is selecting a certain reporting area and examining it in depth in the hopes of determining the author's underlying intents and goals. Thematic analysis is the second method. This relates to the overall sample of texts used in the study, as well as the categorization methods used to identify various elements of the text, which are subsequently counted with an emphasis on objectivity and dependability. The third strategy is to internalize the encoding process, particularly the goals that drive the production of mass media material. The fourth strategy is to concentrate on the content.

\section{REFERENCES}

Abujamous, I., Jawabreh,O., Jahmani, A., Alsarayreh, M., \& Harazneh, A. (2018). Developing tourism through sports events to assist in the rejuvenation of the strategic position of the Aqaba Special Economic Zone Authority (ASEZA). African Journal of Hospitality, Tourism and Leisure, 8 (4), 1-14.

Alananzeh, O.A., Masadeh, R., Jawabreh, O., Mahmoud, A.A., \& Hamada, R. (2018). The Impact of Customer Relationship Management on Tourist Satisfaction: The Case of Radisson Blue Resort in Aqaba City. Journal of Environmental Management and Tourism, 9(2), 227. https://doi.org/10.14505//jemt.v9.2(26).02

Ángeles, M., Sanfiel-Fumero, M., Yaiza, A., \& González-Morales, O. (2017). Sustainability of the tourist supply chain and governance in an insular biosphere reserve destination: the perspective of tourist accommodation. European Planning Studies .25(7), 12561274. https://doi.org/10.1080/09654313.2017.1319466

Anna, S. (2005). Nature-based Tourism and Environmental Sustainability in South Africa. Journal of Sustainable Tourism, 13(2), 136170. https://doi.org/10.1080/09669580508668483

Aragon-Correa, J.A., Martin-Tapia, I., \& de la Torre-Ruiz, J. (2015). Sustainability issues and hospitality and tourism firms' strategies: Analytical review and future directions. International Journal of Contemporary Hospitality Management, 27 (3), $498-$ 522. https://ezlibrary.ju.edu.jo:2057/10.1108/IJCHM-11-2014-0564

Aswita, D., Suryadarma, I.G.P., \& Suyanto, S. (2018). Local wisdom of Sabang island society (Aceh, Indonesia) in building ecological intelligence to support sustainable tourism. GeoJournal of Tourism and Geosites. 22(2), 393-402. https://doi.org/10.30892/gtg.22210-297

Azilah, K., Gursoy, D., Okumus, F., \& Wong, A. (2014). The importance of water management in hotels: a framework for sustainability through innovation. Journal of Sustainable Tourism, 22(7), 1090-1107. https://doi.org/10.1080/09669582.2013.873444

Bagozzi, R.P., \& Yi, Y. (1988). On the evaluation of structural equation models. Journal of the academy of marketing science, 16(1), 74-94.

Berezan,O., Carola, R., Michelle, Y., Curtis, L. (2013). Sustainable hotel practices and nationality: The impact on guest satisfaction and guest intention to return. International journal of hospitality management, 34, 227-233. https://doi.org/10.1016/j.ijhm.2013.03.010

Blomme, R., Van Rheede, A., \& Tromp, D. (2013). The hospitality industry : An attractive employer? An exploration of students' and industry workers' perceptions of hospitality as a career field. Journal of Hospitality \& TourismEducation 21(2). https://doi.org/10.1080/10963758.2009.10696939

Chan, E.S.W., \& Hsu, C.H.C. (2016). Environmental management research in hospitality. International Journal of Contemporary Hospitality Management, 28 (5), 886-923. https://ezlibrary.ju.edu.jo:2057/10.1108/IJCHM-02-2015-0076

Cheng-Yue, Y., Fan, D., \& Yong, C. (2020). Types of green practices, hotel price image and consumers' attitudes in China: the mediating role of consumer skepticism. Journal of Hospitality Marketing \& Management, 29(3), 329-357.

Chen, J. ( 2009). Advances in hospitality and leisure, Emerald Group Publishing, New York. 
Chin, W.W. (2010). How to write up and report PLS analyses. In Handbook of partial least squares, 655-690, Springer, Berlin, Heidelberg.

Christopher, W., Susanne, B., \& Alexandra, C. (2018). Sustainability-oriented Service Innovation: fourteen-year longitudinal case study of a tourist accommodation provider. Journal of Sustainable Tourism, 26(10), 1784-1803. https://doi.org/10.1080/09669582.2018.1511721

Demetra, L., Orthodoxou, X.I., Loizidou, A.G., Stephanie, H., Demetra, P., \& Kyriaki, D. (2021). Sustainable business events: The perceptions of service providers, attendees, and stakeholders in decision-making positions. Journal of Convention \& Event Tourism, 1-25. https://doi.org/10.1080/15470148.2021.1964666

Eirini, S., \& Constanza, P. (2019). Social-ecological dynamics and water stress in tourist islands: the case of Rhodes. Greece. Journal of Sustainable Tourism, 27(9), 1-19. https://doi.org/10.1080/09669582.2019.1630420

Emmanouela, E., Manganari, D., \& Theotokis, A,. (2016). Greening the lodging industry: Current status, trends and perspectives for green value. Current Issues in Tourism. 19(3) 223-242. https://doi.org/10.13140/RG.2.2.20781.90081

Eshun, G., \& Tichaawa, T.M.. (2020). Community Participation, Risk Management and Ecotourism Sustainability Issues in Ghana. GeoJournal of Tourism and Geosites, 28(1), 313-331. https://doi.org/10.30892/gtg.28125-472

Erdogan, N., \& Baris, E. (2007). Environmental protection programs and conservation practices of hotels in Ankara, Turkey. Tourism Management, 28(2), 604-614.

Fanni,Z., \& Rezazadeh, S.M. (2018). Analysing the Urban Environment Sustainability Influenced by Tourism in Iran (District 1 Of Tehran Metropolis). GeoJournal of Tourism and Geosites, 23(3), 719-730. https://doi.org/10.30892/gtg.23308-322

Gomez-Conde, J., Lunkes, R.J., \& Rosa, F.S. (2019). Environmental innovation practices and operational performance: The joint effects of management accounting and control systems and environmental training. Accounting, Auditing \& Accountability Journal, 32 ( 5), 1325-1357. https://ezlibrary.ju.edu.jo:2057/10.1108/AAAJ-01-2018-3327

Hardy, A.L., \& Beeton, R.J.S. (2001). Sustainable Tourism or Maintainable Tourism: Managing Resources for More Than Average Outcomes. Journal of Sustainable Tourism, 9, ( 3). https://doi.org/10.1080/09669580108667397

Heydari, A., \& Bakhtar, S. (2018). Analyzing the regional development of kurdish border cities of Iran using sustainable urban development indices (Study area: Kurdistan Province). GeoJournal of Tourism and Geosites, 23(3), 797-807. https://doi.org/10.30892/gtg.23315-329

Hwai-Shuh, S. (2012). The greener, the more cost efficient? An empirical study of international tourist hotels in Taiwan. International Journal of Sustainable Development \& World Ecology, 19(6), 536-545. https://doi.org/10.1080/13504509.2012.741627

Hwan, S.C.C., \& Ercan, S. (2005). Sustainability indicators for managing community tourism. Tourism Management, 27, ( 6), 12741289. https://doi.org/10.1016/j.tourman.2005.05.018

Idahosa, L.O. (2019). Understanding environmental sustainability, corporate social responsibility and responsible tourism in literature vs practice. GeoJournal of Tourism and Geosites, 26(3), 956-973. https://doi.org/10.30892/gtg.26322-410

Iraldo,F., Testa, F., Lanzini, P., \& Battaglia, M. (2017). Greening competitiveness for hotels and restaurants. Journal of Small Business and Enterprise Development, 24 (3), 607-628. https://ezlibrary.ju.edu.jo:2057/10.1108/JSBED-12-2016-0211

Jawabreh, O., Jahmani. A., Khaleefah, Q., Alshatnawi, E., \& Abdelrazaqe, H. (2020). Customer Expectation in Five Star Hotels in Aqaba Special Economic Zone Authority (ASEZA). International Journal of Innovation, Creativity and Change, 11, (4).

Jawabreh, O. (2017). Distinction of Jordan as a destination for religious tourism. Journal of Environmental Management and Tourism, 6(22), 1171-1182. https://doi.org/10.14505/jemt.v8.6(22).03

Jens, K., \& Steen, J. (2007). Monitoring Motoring: A Study of Tourists' Viewpoints of Environmental Performance and Protection Practices. Scandinavian Journal of Hospitality and Tourism, 7(2), 104-119. https://doi.org/10.1080/15022250701300801

Jinha, L., \& Youn-Kyung, K. (2020). Online Reviews of Restaurants: Expectation-Confirmation Theory. Journal of Quality Assurance in Hospitality \& Tourism , 21(5), 582-599. https://doi.org/10.1080/1528008X.2020.1712308

Jones, P., Hillier, D., \& Comfort, D. (2016). Sustainability in the hospitality industry: Some personal reflections on corporate challenges and research agendas. International Journal of Contemporary Hospitality Management, $28(1)$, 36-67. https://ezlibrary.ju.edu.jo:2057/10.1108/IJCHM-11-2014-0572

Jones, P., Hillier, D., \& Comfort, D. (2014). Sustainability in the global hotel industry. International Journal of Contemporary Hospitality Management, 26 ( 1), 5-17. https://ezlibrary.ju.edu.jo:2057/10.1108/IJCHM-10-2012-0180

Karim, S., Kusuma, B.J., \& Mahfud, T. (2019). Application the development of Balikpapan bay based on sustainable tourism. GeoJournal of Tourism and Geosites, 24(1), 29-38. https://doi.org/10.30892/gtg.24103-340

Kang, K.H., Stein, L., Heo, C., \& Lee, S. (2012). Consumers' willingness to pay for green initiatives of the hotel industry. International Journal of Hospitality Management, 31(2), 564-572. https://doi.org/10.1016/j.ijhm.2011.08.001

Karolina, B., Fabian, W., \& Dorothea, S. (2017). Sustainability Management of Hotels: How Do Customers Respond in Online Reviews? Journal of Quality Assurance in Hospitality \& Tourism, 18(3), 282-307. https://doi.org/10.1080/1528008X.2016.1230033

Kirk, D.(1995). Environmental management in hotels. International Journal of Contemporary Hospitality Management, 7 ( 6), $3-8$. https://doi.org/10.1108/09596119510095325

Kuqi,B. (2018). Teoretical Approach Concerning the Development of Sustainable Tourism as Tourist Destination in Kosovo. GeoJournal of Tourism and Geosites, 22(2), 489-496. https://doi.org/10.30892/gtg.22218-305

Lei, T., Jackie, O., Donovan, S., \& John, M. (2011). Beyond the Beach: Balancing Environmental and Socio-cultural Sustainability in Boracay, the Philippines. Tourism Geographies, 13(4), 549-569. https://doi.org/10.1080/14616688.2011.590517

Liesbth, K. (2004). Measuring the Sustainability of Tourism in Manuel Antonio and Texel: A Tourist Perspective. Journal of Sustainable Tourism, 12, ( 5). https://doi.org/10.1080/09669580408667247

Maaiah, B.S., \& Wouhoush, O.N. (2020). Jordanian culture and traditions as a driving force for attracting dutch tourists. GeoJournal of Tourism and Geosites, 33(4spl), 1450-1455. https://doi.org/10.30892/gtg.334spl01-592

Masadeh, R., Alananzeh, O., Jawabreh, O., Alhalabi, R., Syam, H., \& Keswani, F. (2019). The association among employee's communication skills, image formation and tourist behaviour: perceptions of hospitality management students in Jordan. International Journal of Culture, Tourism and Hospitality Research, 13(3), 257-272. https://doi.org/10.1108/ijcthr-02-2018-0028

Masa'deh, R., Alananzeh, O., Algiatheen, N., Ryati, R., Albayyari, R., \& Tarhini, A. (2017). The impact of employee's perception of implementing green supply chain management on hotel's economic and operational performance. Journal of Hospitality and Tourism Technology, 8(3), 395-416. https://ezlibrary.ju.edu.jo:2057/10.1108/JHTT-02-2017-0011 
María del Mar, M., Alonso-Almeida, L., Bagur-Femenias, JosepLlach, L., \& Perramon, J. (2018). Sustainability in small tourist businesses: the link between initiatives and performance. Current Issues in Tourism, 21(1), 1-20. https://doi.org/10.1080/13683500.2015.1066764

Mensah, I. (2006). Environmental management practices among hotels in the great Accra region. Hospitality Management, 25(3), 414431. https://doi.org/10.1016/j.ijhm.2005.02.003

Molina-Azorín, J,. Claver-Cortés ,E,. Pereira-Moliner, J, \& Tarí, J. (2009). Environmental practices and firm performance: an empirical analysis in the Spanish hotel industry. Journal of Cleaner Production, 17(5). https://doi.org/10.1016/j.jclepro.2008.09.001

Olya, H.L., Altinay, L., Farmaki, A., Kenebayeva, A., \& Gursoy, D. (2021). Hotels' sustainability practices and guests' familiarity, attitudes and behaviours. Journal of Sustainable Tourism, 29(7), 1063-1081. https://doi.org/10.1080/09669582.2020.1775622

Reinartz, W., Haenlein, M., \& Henseler, J. (2009). An empirical comparison of the efficacy of covariance-based and variance-based SEM. International Journal of research in Marketing, 26(4), 332-344. https://doi.org/10.1016/j.ijresmar.2009.08.001

Reinartz, W., Krafft, M., \& Hoyer, W.D. (2004). The customer relationship management process: Its measurement and impact on performance. Journal of Marketing Research, 41, 293-305. https://doi.org/:10.1509/jmkr.41.3.293.35991

Richard, S. (2000). Tourism and Sustainable Development: Exploring the Theoretical Divide. Journal of Sustainable Tourism, 8, ( 1). https://doi.org/10.1080/09669580008667346

Rizal, A., Apriliani, I.M., \& Permana, R. (2020). Sustainability Assessment of Coastal Development in Southern Region of West Java Province, Indonesia. GeoJournal of Tourism and Geosites, 30(2spl), 808-817. https://doi.org/10.30892/gtg.302spl05-509

Pereira-Moliner, J., Font, X., Tarí, J.J., Molina-Azorin, J.F., Lopez-Gamero, M.D., \& Pertusa-Ortega, E.M. (2015). The Holy Grail: Environmental management, competitive advantage and business performance in the Spanish hotel industry. International Journal of Contemporary Hospitality Management, 27 (5), 714-738 . https://ezlibrary.ju.edu.jo:2057/10.1108/IJCHM-12-2013-0559

Sajjad, A., Jillani, A., \& Raziq, M.M. (2018). Sustainability in the Pakistani hotel industry: an empirical study. Corporate Governance, 18 ( 4), 714-727. https://ezlibrary.ju.edu.jo:2057/10.1108/CG-12-2017-0292

Saleh, S., \& Hassan. (2000). Determinants of Market Competitiveness in an Environmentally Sustainable Tourism Industry. Journal of Travel Research ,38 ( 3), 239-245. https://doi.org/10.1177/004728750003800305

Sainaghi, R., Baggio, R., Phillips, P., \& Mauri, A.G. (2018). Hotel performance and research streams: a network cluster analysis. International Journal of Contemporary Hospitality Management, 32 (2), 425-462. https://ezlibrary.ju.edu.jo:2057/10.1108/IJCHM-05-2017-0260

Santos, M.C., Veiga, C., Águas, P., \& Santos, J.A.C. (2019). Sustainability communication in hospitality in peripheral tourist destinations: Implications for marketing strategies. Worldwide Hospitality and Tourism Themes, 11 ( 6), 660-676. https://ezlibrary.ju.edu.jo:2057/10.1108/WHATT-08-2019-0049

Sayfuddin, A. (2021). When green practices affect business performance: an investigation into California's hotel industry. International Review of Applied Economics. https://doi.org/10.1080/02692171.2021.1957784

Singh, A., Rishi, M., \& Shukla, R. (2011). Green management and environmental sustainability: a case of ITC Green Center. Emerald Emerging Markets Case Studies, 1 (2) . https://ezlibrary.ju.edu.jo:2057/10.1108/20450621111159859

Singtuen, V., \& Won-In, K. (2018). Geodiversity and Geoconservation of the Chaiyaphum Region in Thailand for Sustainable Geotourism Planning. GeoJournal of Tourism and Geosites. 22(2), 548-560. https://doi.org/10.30892/gtg.22223-310

Strydom, A.J., Mangope, D., \& Henama, U.S. (2019). Making Community-Based Tourism Sustainable: Evidence from the Free State Province, South Africa. GeoJournal of Tourism and Geosites, 24(1), 7-18. https://doi.org/10.30892/gtg.24101-338

Sloan, P., Legrand, W., \& Chen, J.S. (2013). Sustainability in the hospitality industry: principles of sustainable operations. Routledge, New York.

Sloan, P., Legrand, W., Tooman, H., \& Fendt, J. (2009).Best practices in sustainability: German and Estonian hotels, Chen, J.S. (Ed.). Advances in Hospitality and Leisure (Advances in Hospitality and Leisure, 5), Emerald Group Publishing Limited, Bingley, 89-107. https://ezlibrary.ju.edu.jo:2057/10.1108/S1745-3542(2009)0000005009

Trip, D.T., Fagadar, C.F., Badulescu, D., \& Badulescu, A. (2021). Entrepreneurship and tourism through the lens of sustainability. Charting the knowledge base through bibliometric analysis. GeoJournal of Tourism and Geosites, 34(1), 140-146. https://doi.org/10.30892/gtg.34118-629

Sweeting, J., \& Sweeting, A. (2002). A practical guide to good practice: managing environmental and social issues in the accommodation sector, UNEP Publication, New York

Wang, S.P., Chen, Y.C., Lee, C.T., \& Tsai, A. (2013). Developing green management standards for restaurants: an application of green supply chain management. Int. J. Hospitality Manage., 34, 263-273.

Webster, K. (2000). Environmental management in the hospitality industry: a guide for students and managers. Cengage Learning EMEA, New York.

Wyngaard,A.T., \& Lange, R. (2013). The effectiveness of implementing eco initiatives to recycle water and food waste in selected Cape Town hotels. International Journal of Hospitality Management, 34, 309-316.

Xing, H., \& Kara, C. (2013). Perception of Green Hotels Among Tourists in Hong Kong: An Exploratory Study. Services Marketing Quarterly 34(4), 339-352.

Xun, Xu., \& Dogan, G. (2015). A Conceptual Framework of Sustainable Hospitality Supply Chain Management. Journal of Hospitality Marketing \& Management, 24(3), 229-259. https://doi.org/10.1080/19368623.2014.909691

Yaiza, A. (2011). Determinants of environmental management and implications for firms' economic performance. Journal of Environmental Planning and Management, 54(8), 1077-1106. https://doi.org/10.1080/09640568.2010.549401

Zhang, J.J., Joglekar, N., \& Verma, R. (2012). Pushing the frontier of sustainable service operations management: Evidence from US hospitality industry. Journal of Service Management, 23 (3), 377-399. https://ezlibrary.ju.edu.jo:2057/10.1108/09564231211248462

Zhenhua, L. (2003). Sustainable Tourism Development: A Critique. Journal of Sustainable Tourism, 11(6):459-475. https://doi.org/10.1080/09669580308667216

*** UNEP. ( 2001). Sowing the seeds of change: an environmental teaching pack for the hospitality industry, A joint publication with the International Hotel and Restaurant Association and the International Association of Hotel Schools (EUHOFA International), Paris.

Article history: Received: 22.05.2021 Revised: 24.08.2021 Accepted: 10.09.2021 Available online: 22.10 .2021 